УДК 378:81'271

DOI: $10.15587 / 2313-8416.2015 .36496$

\title{
ПРИКЛАДНІ АСПЕКТИ ПРОЕКТУВАННЯ ЗМІСТУ НАВЧАННЯ ЛЕКСИКОЛОГІЇ ТА ФРАЗЕОЛОГІї МАЙБУТНІХ УЧИТЕЛІВ ПОЧАТКОВОЇ ШКОЛИ
}

\author{
(C) М. М. Греб \\ У статті розглядаються прикладні аспекти проектування змісту навчання лексикології і фразеології май- \\ бутніх учителів початкової школи на засадах розвивального навчання, які реалізуються поетапно (теоре- \\ тичний, практичний, пошуково-дослідницький етапи та етап самостійної роботи) $i$ забезпечуються сис- \\ темою вправ $i$ завдань трьох рівнів складності, щчо сприяють підвищенню мотивації, саморозвитку, само- \\ реалізації суб'єктів навчального прочесу
}

Ключові слова: розвивальне навчання, поетапне навчання лексикологї і фразеології, майбутні учителі початкової школи

In the article it is considered the applied aspects of content projecting of lexicology and phraseology teaching of future primary school teachers basing on the principles of developing education. These principles are realized gradually (theoretical, practical, research stages and stage of independent work). Also these principles are guaranteed by the system of exercises and tasks of three levels of complexity which promotes increasing of motivation, self-development, self-realization of subjects of educational process

Keywords: developing education, lexicology and phraseology gradual teaching, future primary school teachers

\section{1. Вступ}

Суспільна практика свідчить, що будь-які перетворення, у тому числі і в системі вищої педагогічної освіти, не дають належного результату, якщо вони здійснюються методом спроб і помилок, без науково обгрунтованих підходів, інноваційних технологій навчання, методичної системи для професійної підготовки кожного педагогічного працівника через розроблення і реалізацію спеціальних програм розвитку, саморозвитку і самореалізації особистості.

\section{2. Постановка проблеми}

Проектування змісту навчання лексикології i фразеології майбутніх учителів початкової школи на засадах розвивального навчання доцільно здійснювати в кількох напрямах: оволодіння системою знань і оперування ними, оволодіння системою дій, операцій та прийомів навчальної роботи (уміння, навички, фахова компетентність), становлення і розвитку, коригування мотивації навчання; особистісна настанова на аналіз змістової правильності мовлення та виявлення і виправлення помилок у власному і чужому мовленні; уміння редагувати власне і чуже мовлення; удосконалення способів управління навчально-пізнавальною діяльністю та контролем над нею. Така схема потенційно можливої співдіяльності суб'єктів навчання репрезентує зміст різнопредметного навчального матеріалу, який обумовлений метою навчання і знаходить свою опредметнену форму в засобах навчання, відповідає положенню загальної дидактики: змістом кожного навчального предмета $є$ знання, уміння, навички, професійна компетентність, а також досвід творчої діяльності.

\section{3. Огляд літератури}

Аналіз і синтез педагогічних досліджень різних етапів розвитку науки дозволив простежити еволюцію поглядів дидактів та лінгводидактів на навчальнопізнавальну і самоосвітню діяльність, їх взаємообумовлену інтеграцію, де відбувається навчання й учіння i проявляються як об'єктно-суб'єктні характеристики загального феномену діяльності, так і суб'єкт-об'єктні, дещо пізніше, суб'єкт-суб'єктні відношення, на основі яких формується пізнавальний інтерес, самоосвітня діяльність, а відтак - розвивальний тип навчання.

Особливий інтерес досліджуваної проблеми в контексті статті становлять значні напрацювання науковців, у яких висвітлено теоретичні проблеми вивчення української лексикології і фразеології в школах різних типів (О. Біляєв, А. Богуш, Л. Варзацька, М. Вашуленко, Н. Голуб, А. Зеленько, В. Камиш, С. Караман, К. Климова, Т. Коршун, А. Мановецька, Л. Мисечко, Н. Модовцева, В. Новоселова, В. Тихоша, О. Хорошковська, В. Юдін та ін).

Водночас аналіз наукових джерел і спеціальних досліджень засвідчив недостатність теоретикометодологічних напрацювань, у яких би комплексно та системно розроблялося питання прикладних аспектів навчання української лексикології і фразеології майбутніх учителів початкової школи.

Метою статті $\epsilon$ розгляд і реалізація практичного аспекту навчання української лексикології і фразеології майбутніх учителів початкової школи на засадах розвивального навчання.

\section{4. Проектування змісту навчання лексиколо-} гії і фразеології на засадах розвивального навчання

Розвивальне навчання тлумачиться нами як заздалегідь спроектована розподілена співдіяльність на різних процесуальних етапах і видах з виокремленням плану дій, спрямованих на реалізацію мети, завдань, методів та прийомів для задоволення фахових потреб у процесі навчання тих чи тих основних розділів сучасної української мови майбутніх учителів початкової школи. Розподілена співдіяльність є включеною до навчального процесу, що передбачає проектування змісту навчання лексикології і фразеології, передбачати перебіг діяльності на всіх етапах: етап теоретичного засвоєння; етап практичного вивчення; пошуководослідницький етап та етап самостійної роботи. 
До запропонованого проекту розвивального навчання належать:

- зміст діяльності та результат - готовність до навчання, мотивація до самовдосконалення, саморозвитку, саморегуляції;

- методи і прийоми навчання, спрямовані на мотиваційну підтримку діяльності;

- навчальні дії, операції та етапність їх виконання;

- самопрезентація (розроблення проектів, рефератів, виступів, участь у проведенні круглих столів, семінарів, обмін досвідом).

Через проектну сутність розвивального навчання можна оцінити якість за потенціалом реалізації, за прогнозованим продуктом проекту, тобто за ступенем наближення навчальної діяльності, яка планується, до оптимальної, продуктом якої є досягнення високої результативності шляхом моніторингу якості виконаних студентами вправ і тестових завдань.

Ефективними умовами розвивального навчання, апробованими експериментально, визначено такі форми діяльності:

- свідоме оволодіння теоретичним матеріалом;

- застосування знань у розв'язанні пізнавальних та практичних завдань;

- передавання знань іншим (у діалогічних формах мовлення, бесідах, виступах, статтях);

- використання знань у формах інших видів діяльності (ігрової, дослідницької тощо);

- порівняння, корекція, виявлення слушних та хибних поглядів, тобто як інструментарій для розвитку мислення).

Орієнтація вищого навчального закладу на сучасні підходи до формування фахових компетентностей майбутніх учителів початкової школи передбачає окреслення питомої ваги змісту навчального матеріалу, логічних зв'язків, усвідомлення відношень між мовними одиницями; етапність у процесі вивчення лексикології і фразеології; розроблення індивідуальних модульних навчальних програм різних рівнів складності залежно від конкретних потреб, створення дидактичного комплексу задля вироблення ефективної системи організації навчально-пізнавальної та самоосвітньої діяльності майбутніх учителів початкової школи, що відповідала б запитам трансформованого суспільства.

Відтак фундаментального значення набуває переосмислення підходів до розв'язання завдань сучасної освіти; створення у вищих навчальних закладах високоякісного та високотехнологічного інформаційно-навчального середовища, використання сайтів та розміщення на них анотацій курсів, завдань для самостійної роботи студентів, поточної інформації, запровадження інтерактивного консультування студентів тощо. Розвивальне навчання створює реальні можливості для оптимізації, індивідуалізації, інтеграції та моделювання навчального процесу.

Практичні пошуки вітчизняних вишів у нових соціально-економічних умовах суспільства спрямовано на розроблення інноваційного змісту, навчальновиховного процесу у проектуванні програм професійного й особистісного саморозвитку фахівців.

Перехід до інформаційного суспільства супроводжується інтенсивним потоком інформації, перемі- щенням основного масиву iï на електронні носії, підвищення вимог до повноти, оперативності, достовірності інформації, яка надається користувачам, забезпечення доступу до неї з будь-якого місця і в будьякий час.

В інформаційному суспільстві продукується i використовується інтелект, знання, тому майбутній учитель початкової школи має володіти здатністю до особистісного та професійного розвитку і творчості та опанувати вміння інтенсивно працювати в електронному освітньо-розвивальному середовищі. Однією 3 найбільш цінних властивостей освітньо-розвивального середовища $є$ діалогічна форма діяльності 3 комп'ютером на всіх етапах розвивального навчання.

Щоб комп'ютер став справжнім помічником для суб'єктів навчального процесу, передовсім треба створити комп'ютерні навчальні програми, які, $з$ одного боку, слугували б основною для створення сценаріїв навчальних програм для персональних комп'ютерів, а 3 іншого - для унаочнення виучуваної теми чи розділу.

Для прикладу розглянемо сценарій навчальної програми до теми «Лексикологія і фразеологія української мови» за пропонованими етапами розвивального навчання.

Не першому етапі (теоретичний етап) майбутнім учителям пропонуються найрізноманітніші завдання, якими передбачено озброєння студентів знаннями про слово як одиницю мови; найважливіші ознаки слова; типи лексичних значень слів; омоніми, пароніми, синоніми, антоніми, перифрази, евфемізми в українській мові; активна і пасивна лексика; лексика української мови $з$ погляду іiі походження та за сферою вживання; типи фразеологічних одиниць; системні зв'язки в українській фразеології; вживання фразеологізмів в різних стилях мовлення.

Наведемо деякі зразки завдань для першого emany розвивального навчання.

1. Проаналізуйте висловлювання учених про слово. Спробуйте дати визначення, що таке слово.

2. Складіть схему «Слово як об'єкт вивчення».

1. У мові є одиниця, без вивчення якої немислиме пізнання механізму мови. Ця одиниця - слово. Видатний швейцарський лінгвіст Фердинанд де Соссюр зазначив, що слово, незважаючи на всі труднощі, пов'язані з визначенням цього поняття, є одиницею, яка невідступно постає перед нашим розумом як щось центральне в механізмі мови.

2. Слово - наше найзіркіше око, наймогутніша сила. Через слово людина пізнає те, що недоступно було (або залишається таким!) безпосередньому сприйманню. $\mathrm{y}$ цьому диводійному дзеркалі відображаються всі «айсберги» світу. У слові постають перед нашим зором сторінки давньої історії і здобутки майбутнього. Промовляють до нас високі снігові вершини гір, водоспади Америки й Африки, льодові пустелі Арктики, глибінь космосу. Стають зримими найдрібніші частинки Всесвіту (I. Вихованецьь).

3. У слові, як у краплі води океан, відображена вся система мови... (С. Бархударов).

4. Свідомість віддзеркалює себе в слові, як сонце у малій краплі води. Слово відноситься до свідомості, як малий світ до великого як атом до космосу. Воно і є малий світ свідомості (Л. Виготський). 
5. ...Слова ... несуть у мозок інформацію і впливають на його формування, розбудову процесів мислення (I. Білодід).

6. Лексикологія (грецьк. lexis - слово, logos вчення) вивчає склад мови і слово як його основну одиницю. 3-поміж інших мовних одиниць слово виділяють такі ознаки: лексичне значення, номінативна функція та інші (А. Грищенко).

3. Прочитайте текст. На які ознаки слова вказує мовознавець? Як називається розділ мовознавства, що вивчає значення слів і виразів? Яке значення слова називається лексичним, а яке - граматичним? Чи всі слова мають ці значення?

Слова схожі на талу невагому хмаринку. Вони всі разом, але кожне й само по собі в усій своїй досконалості: ось так воно вимовляється (це його фонетичний бік), так воно утворюється від інших слів (це його словотворчі відношення), так воно змінюється за формами, приєднуючись до інших слів у реченні (це його граматичні форми). А ось так це слово розквітає всіма гранями своїх значень, якщо навколо немає жодного схожого чи рівного йому, або сумирно пригасить внутрішне його світіння, якщо поруч виявиться більш точне, більш гнучке слово. Тоді ми говоримо про лексичне значення слова, а ширше - про семантичні зв'язки слів. Семантичні означає смислові; термін семантика походить від давньогрецького семантикос - «те, що означає». I справді слово не відображає предмет безпосередньо, воно тільки позначає його умовним символом (В. Колесов).

\section{Практикум \\ II Eman. Eman практичного вивчення або}

Для другого етапу розвивального навчання дібрано завдання трьох рівнів складності:

1) рівень репродукції;

2) рівень умінь;

3) рівень трансформації [10].

Рівнем репродукції передбачено відтворення теоретичних знань $з$ лексикології і фразеології. Рівнем умінь - глибоке розуміння студентами суті проблеми. Третій рівень - рівень трансформації - $\epsilon$ своєрідною базою для одержання нових знань, своєрідним лакмусом для визначення одного із рівнів (низького, середнього, достатнього, високого) сформованості лексичної та фонетичної компетентностей майбутніх учителів початкової школи. Наведемо зразки завдань трьох рівнів складності.

1. Доберіть до лексем слово, мати, доля. Бог, Україна поетичні ілюстрації з творів Шевченка;

2. Із поезій українських майстрів слова виберіть назви рослин, дослідіть їх етимологію, пригадайте легенди, пов'язані з цими рослинами;

3. Підкресліть слова і словосполучення, що вжиті в переносному значенні, з'ясуйте їх значення i стилістичну роль.

1. Хтось вересень веде по ниві на золотому поводу вечірніх променів.

2. Виходить осінь на орбіту по круглих спинах кавунів. Це вересень.

3. Горобини рожеве намисто приміряють уже снігурі.
4. Листопад сни терпкі колихає по тернових кущах.

5. Звозить осінь своє збіжжя, по стерні бреде лелека. (3 тв. В. Морданя).

4. Прочитайте текст. 3 поданих у дужках синонімів доберіть найбільш доцільний. Обгрунтуйте свій вибір.

Пізня осінь. Вечоріє. Сонце (торкається, дотикається, доторкається, приторкається, черкається) до чорного (небосхилу, небозводу, горизонту, крайнеба). Гори й долини (охоплює, огортає, оповиває, обгортає) вечірня мла. В степу тихо, тихо. Зачаровані красою нашої рідної природи, стоїмо на високій степовій могилі, перед нами (розкинулися, простяглися,розклалися) села, на (виднокрузі, видноколі, небозводі, горизонті) - ліс. (В. Сухомлинський).

5. Випишіть із фольклорних збірників та запам'ятайте п'ять-шість народних прислів'їв і приказок про слово.

Зразок:

1. Слово до слова - зложиться мова.

2. Гостре словечко коле сердечко.

3. Слово - не стріла, а глибше ранить.

4. Що вимовиш язиком, того не виб'єш і кілком.

5. Слово - не горобець: вилетить - не піймаєш.

\section{Рівень уміння}

6. Виділені в тексті слова замініть синонімами, користуючись синонімічним словником.

На ясному весняному небі тихо линуть каравани хмар. Он одна 3 них зачепилася за вершину гори і повисла, розгорнувши свої розлогі крила. Інші легко промчали повз скелі і полетіли далі над безмежним степом.

Довідка: ясний - погідний, безхмарний, чистий; вершина - верхівця, верхівка, верховина, шпиль; розлогий - широкий, просторий, обширний; полетіти - помчати, понестись, полинути; безмежний - безкраїй, безконечний, неосяжний, неоглядний, неозорий.

7. З'ясуйте, коли вживаються слова отара, maбун, череда, зграя, ватага; складіть з ними словосполучення. (Отара овець, табун коней, череда корів, зграя вовків, ватага хлопців).

8. Поясніть відтінки значень слів у синонімічних рядах: старий, літній, дряхлий; кволиц̆, слабосилий, немічний, безсилий; говорити, кричати, лепетати, гаркнути.

9. Згрупуйте подані нижче слова в синонімічні ряди. Холодна, прийшла, кружляти, рипить, хуртовина, скрипить, люта, заметіль, різкий, настала, віхола, літати, хуга, пронизливий, покрив, устелив, позаносив, шумить, гуде. З'ясуйте, в яких групах слів спільнокореневі слова, а в яких - синоніми. Дорога, шлях, путь; дорога, доріженька, подорожник; кордон, межа, край; кордон, прикордонник; друг, приятель, товариш; друг, дружок, дружище; тихий, спокійний, неголосний; тихий, тихенький, тиша.

10. Доберіть до запозичених слів їх українські відповідники. Стюардеса, (бортпровідниця), оратор (промовець), інформація (повідомлення), дистаниція (відстань), експорт (вивезення), імпорт (увезення), коментар (пояснення), делегат (посланець).

11. Прочитайте назви книжок, що складаються лише з імені головного героя. Допишіть декілька своїх 
прикладів. Поясніть правопис великої букви. «Катерина» (Т. Шевченко); «Зоя» (М. Алігер); «Алінка» (К. Гриб); «Маркіян» (В. Кав); «Климко» (Г. Тютюнник); «Сашко» (Л. Смілянський); «Пилипко» (А. Головко); «Дениско» (С. Гуцало); «Марія» (О. Іваненко); «Олеся», «Ксеня», «Грицько» (Б. Грінченко), «Харитя» (М. Коцюбинський).

13. Поміркуйте, чому у словнику-довіднику С. Головащука «Українське літературне слововживання» чоловічих імен подано більше, ніж жіночих?

14. Розпитайте у старших людей про народні обряди вашого регіону і запишіть ці розповіді у формі інтерв'ю, повідомлення, оповідання або іншого жанру.

15. Прочитайте текст. Напишіть твір-роздум «Листку подібний над землею, що вітер з дерева зрива, хто мову матері своєї, як син невдячний, забува». (B. Сосюра).

Я глибоко переконаний, що не існує мертвих мов. Слова живі, радіоактивні. У них різна енергетична наповненість Але існують мови спотворені, словапокручі, слова-потвори, слова-вампіри, які висмоктують людську енергію, збіднюючи таким чином світ, поглинаючи космічну енергію... Треба боятися цих слів, абревіатурних утворень, паразитів нашої свідомості, які вампіризують у нас. Слова ці не мироносні, а життєзгубні. 3 ними потрібно боротися, протиставляючи їм слова духоповні. Хвороба мови - це хвороба світу, це космічний дисбаланс... Потрібні великі загальнонародні зусилля для оздоровлення нашої мови... (П. Мовчан).

16. За поданим початком створіть текстрозповідь з елементами роздумів про одну із річок рідного краю.

Дніпро називають річкою трьох держав. Великий і повноводий наш Дніпро. Серед його 847 приток $€$ такі великі ріки, як Березина і Прип'ять, Сула і Десна.

17. Користуючись словниками або науковопопулярною літературою, дайте наукове тлумачення назви вашої річки та кількох термінів фауни і флори рідного краю.

18. Випишіть із текстів художньої літератури цікаві описи птахів, квітів, рідного міста, села, краю, доповнивши їх власними роздумами.

19. Чим, на вашу думку, відрізняється лексичне значення слів: вірний, правдивий, правильний, певний, слушний, вірогідний, імовірний! Складіть із ними речення. Перевірте, чи збігаються ваші міркування із поясненнями, вміщеними у поданих наукових текстах.

1. Вірний, правдивий, правильний, певний, слушний.

Останнім часом прикметник вірний заполонив як усне, так і писемне мовлення, часто вживаючись у невластивому йому значенні: повів на вірну загибель бійців; знайшов вірний шлях; вірно робить син. А тим часом в українській класиці і фольклорі ці слова вживались у вужчому значенні. Слово вірний означає «відданий»: пісня).

1. Ой вийди, вийди, дівчино моя вірная. (Нар.

2. Без вірного друга велика туга. (Прислів'я). Якщо мова йде про правильність, слушність, певність, то вживали прикметники певний, правильний, правдивий

3. А щзоб певна була правда, - нехай шлях покаже. (Т. Шевченко).
4. Мандрівники намагались знайти правильний напрям.

5. Артем чекав на слушну хвилину. (А. Головко). Отже, слід говорити і писати: на певну загибель; правдивий илях, слушно робить син.

2. Вірогідний та ймовірний.

Ці прикметники часто вважають за тотожні i помиляються: 1. Я знаю про ие з імовірних джерел. 2. Таке припущення - вірогідне. А треба було написати навпаки: в першій фразі - вірогідних, у другій - iмовірне. Прикметник вірогідний означає «цілком певний, цілком правдивий, достеменний, перевірений», а ймовірний - це «той, що його можна тільки припустити». Наприклад: 1. Вірогідні написання букви «і» замість «о» починаються з $X I V-X V \mathrm{~cm}$. (А. Кримський). 2. Пригоди були довгі, плутані $i$ завжди переходили межі ймовірного. (В. Козаченко).

\section{Рівень трансформації}

20. Користуючись тлумачним та етимологічним словниками, з'ясуйте значення та етимологію слів щастя і доля, доведіть, що вони є семантичними дублетами, чи випадково слово щастя і доля об'єдналися в одне складне слово-поняття - щастя-доля, випишіть із фразеологічних та тлумачних словників фразеологізми 3 цими словами, згрупуйте їх тематично.

21. Пригадайте назви творів - крилаті вислови, встановіть походження цих висловів.

22. Доберіть якомога більше прислів'їв, у складі яких є власні назви, простежте, які імена найчастіше вживаються в них, дослідіть походження цих імен.

23. Випишіть із словників фразеологізми, у складі яких уживаються опорні слова: вода, роса, тематично погрупуйте ïx, поміркуйте, як народились ці фразеологізми.

24. Прочитайте фразеологізми українською й англійською мовами. Визначте, в чому національна особливість кожного із фразеологізмів.

1. Make (або give) room (tor), to - поступатися місцем, звільняти місце (для когось), посунутися, відступити;

2. Make semblance of something, to (to put on a semblance of something) - надіти личину, удавати, зробити вигляд;

3. Make sense, to - мати смисл; бути зрозумілим;

4. Make (або cast) sheep's eyes at one, to - дивитися на когось закоханими очима;

5. Mair-weather friend (waiter upon Providence) друг до першої біди, ненадійний друг;

6. Fair without, false (або foul) within - красиве зовні, та гниле всередині;

7. Fair word and no favour - чесне ставлення на словах і на ділі;

8. Fair (060 good) words - слова примирення, ласкаві слова; компліменти, лестощі;

9. Faithful Adam, the - вірний старий слуга (за ім'ям персонажа у комедії В. Шекспіра As You Like it).

10. Close vote - а майже рівна кількість «за» $\mathrm{i}$ «проти» (при голосуванні);

11. Clothes make the man - присл. 1) одяг робить людину; 2) і пень прибери, то гарним буде;

12. Cloud on one's happiness - те, що затьмарює щастя, радість. 
13. Club law (тж. club-law) - 1) кулачне право, право сильного; 2) статут клубу.

\section{III етап - пошуково-дослідницький}

Завдання пошуково-дослідницького характеру привчають студентів бачити проблему, знаходити ефективні шляхи іiі розв'язання, розвивають гіпотетичне мислення, стимулюють творчу, пошуководослідницьку діяльність, вчать будувати докази, робити висновки, досліджувати предмет або явище, сприяють формуванню пізнавальних інтересів.

1. Поясніть стилістичні особливості слів із синонімічними афіксами (океанний - океанічний, чарівний - чарівливий).

2. Знайдіть в улюбленому творі авторські новотвори, поясніть, за якими моделями вони створені, умотивуйте їх доречність (віконця - прозори, свавільна тудисюдність та ін.).

3. Напишіть якомога більше асоціативних означень до слова барви, порівняйте їх 3 авторськими, 3 поданого уривка випишіть похідні іменники, визначте ïx морфемну структуру: Барви, мов люди, бувають веселі, чисті, лагідні, довірливі, невинні, сумні, нудьгуючі, крикливі, жалібні, холодні, теплі, м'які, тверді, гостpi, тихі, гризливі, солодкі, млосні, терпкі, урочисті, тяжкі, понурі, вбивчі. Він знав тепер, що червона барва означає кохання й милосердя, небесна - вірність, радість, зелена - надію, вдячність, чорна - жалобу, смуток, а жовта - ненависть, зраду, золота ж - святість, досконалість, мудрість, повагу (П. Загребельний).

4. Уважно розгляньте карту України й випишіть назви міст, що закінчуються на -поль (наприклад: Севастополь) та -nіль (наприклад: Тернопіль). Дослідіть, на якому терені переважають перші назви, а на якому другі. Поміркуйте, чому це так.

5. Прочитайте виразно вірш, знайдіть слова 3 переносним значенням, 3'ясуйте, 3 якою метою їх використовує автор:

Тече вода 3-під явора

Яром на долину

Пишається над водою

Червона калина,

Пишається калинонька,

Явір молодіє.

А кругом їх верболози

Й лози зеленіють... (Т. Шевченко).

6. Ознайомтеся з описом обряду сватання у п'єсі Т. Шевченка «Назар Стодоля», укладіть тематичний словник «Українські обряди».

7. Чим, на вашу думку, відрізняється вживання слів: брама - вежа, дружний-дружній, надпий - звабливий, відпочивальники - ті, щчо відпочивають. Перевірте, чи збігаються ваші міркування з тими, що наведені в книзі Б. Антоненка-Давидовича «Як ми говоримо».

8. Дослідіть поетичну етимологію назв творів Василя Симоненка, Ліни Костенко, Лесі Українки.

На третьому етапі доцільно заздалегідь ознайомлювати студентів із тематикою для написання рефератів, лінгвістичних повідомлень, що охоплюють важливі проблеми лексикології та фразеології.

Орієнтовна тематика може бути такою:

1. Лексичний склад і структура прізвищ родини, друзів, однокурсників, видатних діячів науки й культури.
2. Динаміка чоловічих та жіночих імен.

3. Мовні засоби для зображення комічного i смішного у новелах Михайла Коцюбинського.

4. Особливості структури синтаксичних конструкцій українських казок, легенд, прислів"їв.

5. Трансформація фразеологізмів як засіб створення сатирично-гумористичного ефекту (на матеріалі романів Олега Чорногуза та Євгена Гуцала).

6. Символіка чисел в поезії Свгена Плужника (лінгвістичний аспект).

7. Роль повторів у творах Олександра Довженка.

8. Семантико-стилістичне явище гри слів на рівні морфеміки та словотворення (на матеріалі поезії Ліни Костенко).

9. Метафора як засіб образного моделювання світу (на матеріалі поетичних творів Володимира Свідзинського).

10. Природа морфологічних явищ у системі словозміни українського дієслова (на матеріалі творів Панаса Мирного).

11. Синтаксична організація пейзажних описів у віршах Тараса Шевченка.

Наведемо приклад лінгвістичного повідомлення одного із студентів, який було опрацьовано на третьому етапі розвивального навчання 3 теми «Історія вивчення міжмовної лексики».

\section{5. Історія вивчення міжмовної лексики}

Історія вивчення міжмовної лексики дещо контрастує 3 епізодичним дослідженням фразеологічних міжмовних контактів у лінгвістичних студіях. Висновки, правомірні для лексичних мовних контактів, не завжди можуть бути екстрапольовані на фразеологію. Так, часто явища полігенези, які спостерігаються при лексичних мовних контактах за лінією запозичення, значно менше характерні для фразеології.

Тому у процесі реалізації практичного аспекту змісту навчання фразеології у лінгводидактиці вищої школи доцільно враховувати приналежність мовипосередника до створення фразеологічних одиниць та співвідношення потенційних і реальних етимологічних джерел, оскільки мова - посередник виступає частково творцем тієї чи тієї ФО, якщо в ній відбувається формування власне фразеологізму на основі запозичених уявлень, образів тощо, вербальне вираження яких не може бути визнане як фразеологізм, хоч його прикметною ознакою і $є$ неодноразове відтворення в мові народу, але первинним здобутком виступає передусім зміст конкретного фразеологізму. Наприклад, фразеологічні паралелі: укр. «голос (висок. глас) народу» - нім. die Stimme - das Volkes - poc. «глас народа - глас божий» - болг. «глас народни - глас божи» - англ. the voice of the people is the voice of God.

Розробляючи прикладний аспект змісту навчання фразеології, доцільно акцентувати, що численні епізодичні висловлювання дослідників про міжмовну фразеологію в більшості своїй не $є$ результатом спеціальних досліджень, а відтак, зазвичай, бувають суб'єктивними, що посилюється розглядом міжмовної фразеології з позицій однієї мови і взагалі суперечить смислові міжмовного аспекту.

Розгляд питань фразеології у світлі мовнокультурних контактів доцільно будувати в контексті 
проблем перекладу фразеологічних одиниць та поняття міжмовної фразеологічної еквівалентності (3a С. Денисенко).

На четвертому етапі студентам пропонуються завдання для самостійної роботи (тренувальний тип), що включає виконання та розв'язання стандартних завдань і вправ. Основним методом на цьому етапі роботи є метод спостереження.

Пропонуються також завдання реконструктивно-варіативного, евристичного та дослідницького характеру, якими передбачено опрацювання спеціальної літератури, аналіз, синтез, аргументація, складання планів, тез, конспектів, анотацій, розв'язання проблемних, творчих завдань та завдань дослідницького характеру (написання рефератів, розроблення проектів, презентацій, курсових проектів).

\section{6. Висновки}

Отже, за умов впровадження методики розвивального навчання створюються можливості для активного залучення до формування змісту навчальних програм, з урахуванням їхніх професійних запитів і потреб; оволодіння теоретичними поняттями про слово, лексему, фразеологічну єдність; засвоєння системи правил формування усвідомленого висловлення, збагачення словниковим запасом, опануванням фразеології як окраси мови і разом з тим могутнім стилістичним засобом влучної і дохідливої передачі думки. Пропоновані етапи розвивального навчання $є$ невід'ємною складовою процесу ефективного навчання лексикології і фразеології української мови, сприяють поглибленому оволодінню знань, допомагають розвивати творчий потенціал, зокрема, здатність не лише до засвоєння теоретичного матеріалу, сучасних ідей, перспективних освітніх технологій, а й до реалізації їх у практичній діяльності.

\section{Література}

1. Алексюк, А. М. Організація самостійної роботи студентів в умовах інтенсифікації навчання: Навч. посібник [Текст] / А. М. Алексюк, А. А. Аюрзанайн, Л. І. Підкасистий та ін. - К.: ІСДО, 1993. - 336 с.

2. Алексюк, А. М. Загальні методи навчання в школі [Текст] / А. М. Алексюк; 2-ге вид. - К.: Рад. школа, 1981. $-206 \mathrm{c}$.

3. Вашуленко, М. С. Удосконалення змісту і методів навчання української мови в 1-4 класах. Науково-теоретичні засади та методичні рекомендації. [Текст] / М. С. Вашуленко. - К.: Рад. школа, 1991. - 110 с.

4. Голуб, Н. Б. Самостійна робота студентів з риторики: Навчально-методичний посібник [Текст] / Н. Б. Голуб. Черкаси: Брама - Україна, 2008. - 232 с.

5. Загальноєвропейські Рекомендації з мовної освіти: вивчення, викладання, оцінювання [Текст] / Відділ сучасних мов, Страсбург. - К.: Ленвіт, 2003. - 262 с.

6. Денисенко, С. Вивчення фразеології у світлі мовнокультурних контактів на сучасному етапі: Наукове видання. Матеріали шостої міжнародної наукової конференції. Мова i культура в п’яти томах, том II. [Текст] / С. Денисенко. - К.: Collegium, 1998. - $162 \mathrm{c}$.

7. Кучерук, О. А. Система методів навчання української мови в основній школі: теорія і практика: Монографія [Текст] / О. А. Кучерук. - Житомир: Вид-во ЖДУ ім. І. Франка, 2011. - 420 с.

8. Методика навчання української мови в початковій школі: навчально-методичний посібник для студентів вищих навч. закладів [Текст] / за наук. ред. М. С. Вашуленка. - К. : Літера ЛТД, 2011. - 364 с.

9. Пономарьова, К. М. Робота над синонімами як засобом увиразнення мовлення [Текст] / К. М. Пономарьова // Початкова школа. - 1997. - № 6. - С. 10-15.

10. Пентилюк, М. І. Методика навчання української мови в середніх освітніх закладах [Текст] / М. І. Пентилюк, С. О. Караман, О. В. Караман та ін.; за ред. М. І. Пентилюк. К. : Ленвіт, 2004. - 400 с.

11. Савченко, О. Я. Дидактика початкової школи: Підручник для студ. пед. факультетів [Текст] / О. Я. Савченко. - К.: Абрис, 1997. - 304 с.

12. Симоненко, Т. В. Формування професійної мовнокомунікативної компетенції студентів філологічних факультетів [Текст]: монографія / Т. В. Симоненко. - Черкаси: Вид. Вовчок О. Ю., 2006. - 328 с.

\section{References}

1. Aleksyuk, A. M. (1993). Orhanizatsia samostiynoi roboty studentiv $\mathrm{v}$ umovakh intensyfikatsii navchannia: Navch. posibnyk. Kiev: ISDO, 336.

2. Aleksyuk, A. M. (1981). Zahalni metody navchannia v shkoli. Second edition. Kiev: Rad. shkola, 206.

3. Vashulenko, M. S. (1991). Udoskonalennia zmistu metodiv navchannia ukrainskoi movy v 1-4 klasax. Naukovoteoretychni zasady ta metodychni rekomendatsii. Kiev: Rad. shkola, 110

4. Holub, N. B. (2008). Samostiina robota studentiv z rytoryky: Navchalno-metodychnyi posibnyk. Cherkasy: Brama Ukraina, 232

5. Zahalnoievropeiski Rekomendatsii z movnoi osvity: vyvchennia, vykladannia, otsiniuvannia (2003). Viddil suchasnykh mov, Strasburh. Kiev: Lenvit, 262.

6. Denysenko, S. (1998). Vyvchennia frazeolohii u svitli movno-kulturnykh kontaktiv na suchasnomu etapi: Naukove vydannia. Materialy shostoi mizhnarodnoi naukovoi konferentsii. Mova i kultura v pyaty tomakh, tom II. Kiev: Collehium, 162.

7. Kucheruk, O. A. (2011). Systema metodiv navchannia ukrainskoi movy $\mathrm{v}$ osnovniy shkoli: teoria i praktyka: Monohrafia. Zhytomyr: Vyd-vo ZDU im. I. Franka, 420.

8. Vashulenka, M. S. (Ed.) (2011). Metodyka navchannia ukrainskoi movy $\mathrm{v}$ pochatkovii shkoli: navchalno-metodychnyi posibnyk dlia studentiv vyshchykh navch. Zakladiv. Kiev: Litera LTD, 364.

9. Ponomarova, K. M. (1997). Robota nad synonimamy yak zasobom uvyraznennia movlennia. Pochatkova shkola, 6, 10-15.

10. Pentylшuk, M. I. (2004). Metodyka navchannia ukrainskoi movy $\mathrm{v}$ serednikh osvitnikh zakladakh. Kiev: Lenvit, 400 .

11. Savchenko, O. Ya. (1997). Dydaktyka pochatkovoi shkoly: Pidruchnyk dlia stud. ped. fakultetiv. Kiev: Abrys, 304.

12. Symonenko, T. V. (2006). Formuvannia profesiynoi movnokomunikatyvnoi kompetentsii studentiv filolohichnykh fakultetiv. Cherkasy, 328.

Рекомендовано до публікації д-р пед. наук Караман С. О. Дата надходження рукопису 25.12.2014

Греб Марія Михайлівна, кандидат філологічних наук, доцент, кафедра філологічних дисциплін, Бердянський державний педагогічний університет, вул. Шмідта, 4, м. Бердянськ, Україна, 71112 E-mail. marygreb@mail.ru 